\title{
INDONESIA IS COMBATING CORRUPTION: A Struggle between the Extra-Ordinary Measurement and Extraordinary People
}

\author{
Dini Dewi Heniarti \\ Universitas Islam Bandung \\ e-mail: dini.dewiheniarti@gmail.com
}

\begin{abstract}
Currently, the practices of mafia of law in Indonesia is getting more rampant. Law enforcement is very slow, many cases of corruption offenses as crimes extra ordinary crime are addressed will slow grind lower law. Ineffective of law in Indonesia is also dependent on these factors. Primarily extraordinary people. Several law enforcement officials are easily bribed by corrupt actors with the aim to escape punishment, or lighten their sentences. Laws are formulated to deal with corruption seem barren. Factually Indonesia show that is still ranked below Malaysia, Singapore, and Hong Kong, as well as Vietnam and the Philippines. Outcome in the form of impacts and benefits of combating corruption unclear to this day. This paper will to describe that law enforcement combating corruption will be support by extra ordinary measure and extra ordinary people. Especially, Indonesia, a majority Muslim country in fact the largest Muslim country in the world, a large number of Islam is really potential become a leader in the combating corruption.
\end{abstract}

Praktek mafia hukum di Indonesia saat ini lebih merajalela. Penegakan hukum saat ini sangat lambat, banyak kasus tindak pidana korupsi sebagai kejahatan extra ordinary ditangani lambat laun akan menggiring hukum yang lebih rendah. Tidak efektifnya hukum di Indonesia tergantung juga pada faktor-faktor ini: pejabat penegak hukum yang mudah disuap oleh pelaku korupsi dengan tujuan untuk menghindari hukuman, atau meringankan hukuman mereka; hukum yang diformulasikan untuk menangani korupsi tampaknya mandul. Secara faktual Indonesia masih berada di bawah peringkat Malaysia, Singapura, dan Hong Kong, serta Vietnam dan Filipina dalam hal penanganan korupsi. Tulisan ini akan menjelaskan bahwa penegakan hukum dalam pemberantasan korupsi membutuhkan dukungan dengan tindakan luar biasa dan orang luar biasa. Terutama Indonesia, yang mayoritas penduduknya Muslim benar-benar potensial bagi kelahiran pemimpin yang mampu memerangi korupsi.

Keywords: combating; corruption; law enforcement; extra ordinary measure; extra ordinary people; muslim country 


\section{A. Preface}

Corruption is a deep-rooted old-age phenomenon existing in innumerable forms, no cultural boundaries, operates in the private as well as the public sector, applies to rich and poor countries. Indonesia is one the world's most corrupt countries, according to studies conducted both by the Berlin-based organization, Transparency International, and by the Hong Kong-based organization, Political and Economic Review Risk Consultancy. Corruption applied was not a fixed, uniform one, but based on what is believed in each country. Gift-giving practices in many developing countries in Africa and Asia, based on traditional beliefs, honours or social status, may have been categorised as corruption in western developed countries, but not by traditional gift-giving practitioners. ${ }^{1}$ Most Indonesians perceive that corruption has worsened in the country based on the frequency of electronic and print media outlets producing corruption-related news reports, a survey has revealed.

The State impressed stuttering and defensive handling corruption cases. Handling corruption just satisfying populist moment only. The Law enforcement officials was distorted because it applies to lower society that they did not have access to power. Habit of abuse of power authority, political economy transaction -based exchange of authority, as well as hostage-law in the name of power. The difficulty of law enforcement cells spread to many system of the state such as political, economic, and bureaucratic and to culminate to corruption. The rule of law to in the cage. The Society imposed legal values he believes in himself. The Rules that the frist one fit in place but oversize elsewhere. More intricate that the regulation based on the interpretation of the holder of authority control. Bureaucracy is mixed with subjectivity takes the form of skewed diverse shades crokeed. The Rules that the frist fit in one place but oversize elsewhere. More intricate that the regulation based on the interpretation of the holder of authority control. Bureaucracy is mixed with subjectivity takes the form of skewed diverse shades crooked. Meanwhile, anticorruption campaigns in Indonesia follow a dominant worldview that see corruption as something evil.

\footnotetext{
${ }^{1}$ Aji, B., "Menekan ICOR dengan Antibocor' (Lowering ICOR with Anti-Leak)”, Forum Keadilan, 1995, 11 September, p. 86.
} 
Campaigns against corruption in Indonesia paint it as an extraordinary crime carried out by greedy people. However, Indonesia has stepped considerable up its fight against corruption: In March 2012, the Government of Indonesia issued the President's National Strategy of Corruption Prevention \& Eradication with both medium (2012-2014) and long-term (2012-2025) objectives in order to eradicate corruption within the government, civil society, and the business environment. With its new anti-corruption law and the very powerful Corruption Eradication Committee (KPK), Indonesia is believed to be on the right track to eradicate corruption. Only the last couple of months, several prominent officials have been investigated, trailed and sentenced by the KPK. Corruption cases recent months involve parliament members, governmental representatives, judges, representatives of regulators, police officers and Indonesian- and foreign businessmen.

The kinds of corruption that sufficient attention is indicate $\mathrm{n}$ transactive corruption as a mutual agreement between the donor and the recipient, for the benefit of both parties and actively endeavored to achieve gains by both of them, which usually involves the business community and government. Similarly, nepotistic corruption concerning abuse of power and authority for the various types of benefits for friends or relatives. Transactive corruption as abuse of power and political and economic authority does not take place in a vacuum or isolated, but linked to social conditions that exist and the reality of patronage system that became a feature of the dynamics of the national economic.

Political control of resources inherent in certain strategic positions within the scope of the institutional power of the state, is the potential for discriminatory manner allocate economic resources and facilities in accordance with the business interests of other parties who have a relationship of patronage with the holders of power. This trend is strengthened by the ineffectiveness of supervision by an official supervisory agencies and institutions of democracy that moves limited in spaces which are accommodated reform and state-controlled. The fact that is difficult to deny about symptoms believed to be endemic collusion between business circles with the determinants of operations in areas concerning public finance management. In a persuasive research corruption have the smooth functioning of governance and development are complicated, difficult, long and long winded bureaucratic work can be made of short, smooth and shoot straight with corruption therapy. 
Corruption is the lubricant of development so-called facilitating payments, lubricants, grease or wax. In theory, the bureaucracy has a glorious history in the era of striking at monarchical absolutism. Bureaucracy is born when people are sick with autocracy and aristocracy and absolute monarchy in the seventeenth century in France. When fate is determined as good belly king, prince or other despot. The authority was then divided between the bureau table occupied by officials.

Over the past ten years, the focus on and criticism of the ingrained nature of "KKN" or corruption, collusion and nepotism, in Indonesia's economy has brought out into the open many of the previous administration's misdeeds which went unpunished. However, this is not to say that there were then no penalties for corruption. On the contrary, it is true to say that there has been an ample framework for the punishment of corrupt acts for a long time. However, and as is commonly known, it was of course the absence of effective enforcement of violations of the laws in place, the overwhelming and all-encompassing power of the violators, and the in-built prevalence of corruption throughout the framework of the state's economy, which has led to today's problems in and intense focus on this area.

Along with the increasing openness and ability to criticise which has marked the last few years, has come a strong public desire for the government to act firmly and decisively to deal with the problems of criminal corruption. The government has responded by introducing a number of laws and regulations which have the stated intention of more effectively preventing and eradicating corruption. We will see later how these laws and regulations have tried, over the last eleven years, to make it easier to investigate, prosecute and, ultimately, eradicate the criminal act of corruption.

\section{B. Defining Corruption}

In common usage, the word corruption is associated with a range of acts such as bribery, extortion, buying influence, nepotism, favoritism, fraud and embezzlement. Nevertheless, it is at root evidence of a moral failure. The word corruption comes from the Latin verb rumpere, to break. ${ }^{2}$

\footnotetext{
${ }^{2}$ C. Camerer, “Gifts as Economic Signals and Social Symbols,” American Journal of Sociology, Vol. 94 (supplement), 1988, pp.180-214.
} 
By implication, then, something is broken - presumably a prevailing ethical, moral, social, or administrative code of conduct. In this respect, corruption can be thought of as the betrayal and abuse of trust for private benefit. ${ }^{3}$

A number of corollaries follow. First, there can be no clear distinction between perpetrator and victim. If ethics are good for you, then corruption must be corrosive to the perpetrator, along with society as a whole. Second, there is necessarily a cultural dimension. Such actions as officials demanding bribes are considered corrupt in virtually all societies, whereas attitudes to gift-giving and cronyism, for example, vary from country to country. ${ }^{4}$

Gould have argued that there is no single definition of corruption which can be accepted by all peoples of different places and times. ${ }^{5}$ Corruption may be different from region to region, and from time to time. Some authors have defined corruption simply as power or public role abuse for private gain ${ }^{6}$, but $\mathrm{Nye}^{7}$ proposed a more complex and longer definition of corruption, as: behaviour which deviates from the normal duties of a public role because of private-regarding (family, close private clique) pecuniary or status gain; or violate rules against the exercise of certain types of private-regarding influence.

This includes such behaviour as bribery (use of reward to pervert the judgement of a person in a position of trust); nepotism (bestowal of patronage by reason of ascriptive relationship rather than merit); and misappropriation (illegal appropriation of public resources for private-regarding uses.

Corruption in a significant amount could pose a threat to the stability and security of societies, undermining the institutions and values of democracy,

\footnotetext{
${ }^{3}$ Arnold J. Heidenheimer, (ed.), Political Corruption: Readings in Comparative Analysis (New York: Holt, Rinehart and Winston, Inc, 1970), p. 4.

${ }^{4}$ Samuel P. Huntington, Political Order in Changing Societies (New Haven and London: Yale University Press, 1968), p. 59.

${ }^{5}$ Gould, D.J., 'Administrative corruption: incidence, causes, and remedies' in A. Farazmand. (ed.), Handbook of Comparative Development and Public Administration (New York: Marcel Dekker, 1991), pp. 467-480. 1982).

${ }^{6} J o h n s t o n$, M., Political Corruption and Public Policy in America (California: Brooks/Cole Publishing:

${ }^{7}$ Nye, J.S.r. "Corruption and Political Development: a Cost-benefit Analysis" in M.U. Ekpo (ed.), Bureaucratic Corruption in Sub-Saharan Africa: toward a Search for Causes and Cosequences (Washington D.C: University Press of America, 1979), p. 417.
} 
ethical values and justice, are discriminatory and undermines the ethics and competition honest business, wounding sustainable development and the rule of law as as one of the core values of democracy, among others, must be accompanied tha enforcement of the principle of equality before the law.

Based on this minimalist definition, Alatas ${ }^{8}$ proposes typologies of corruption: 1) transactive corruption', that is corruption that takes place on some kind of agreement between a donor and recipient for mutual gains; 2) extortive corruption', that is corruption which involves extortion to avoid possible legal consequences for those who are involved and close to the actor of corruption; 3) investive corruption', that is corruption which begins with promises - a kind of investment - to anticipate certain gains in the future; 4) nepotist corruption', that is corruption which takes place because of certain favourable treatment in job promotion in public office and in projects for close relatives; 5) autogenic corruption', that is corruption which takes place when a public official gains certain benefits for his/her knowledge as insider (insider's information) on public policies that he/she must otherwise keep secret; 6) supportive corruption', that is protection or even support certain acts of corruption which takes place within power struggle.

Thus, from the minimalist definition, corruption in the end can be divided into a number of typologies and categories. Furthermore, corruption can also be categorized based on its place; in public sector and private; or based on its intensity, isolative or systematic; national or local, personal or institutional, traditional or modern kind of corruption.

All of these categories, typologies and the kinds of corruption would be very helpful not only for a better knowledge of corruption, its causes and consequences, but also for finding the ways to solve it. They would help to formulate strategies to combat corruption; to develop political will against it as well as to mobilize an anti-corruption movement within the public in general. Corruption then can be eliminated by recognizing various categories, typologies and kinds of corruption in certain contexts.

${ }^{8}$ Syed Hussein Alatas, Corruption: Its Nature, Causes and Consequences (Aldershot [UK] and Brookfield VT: Avebury, 1990), pp. 3-4. 


\section{Problematic of Law Enforcement of Combating Corruption based on Extra Ordinary Measure and Extra Ordinary People}

The Komisi Pemberantasan Korupsi (KPK) is the Indonesian Corruption Eradication Commission, which was formed after special consideration on the extraordinary nature of corruption in Indonesia, which has become systemic and widespread, and has violated the human rights of the Indonesian people. The KPK was formed under Law No. 30 of 2002 on the Corruption Eradication Commission. Before the KPK was formed, only Police and Prosecutors had the authority to conduct anti-corruption activities under Law No. 31 of 1999 on Eradicating Criminal Acts of Corruption as amended by Law No. 20 of 2001, and under Law No. 28 of 1999 on State Officials who are Clean and Free of Corruption, Collusion, and Nepotism.

The KPK was formed with the express intent of bringing about positive change in a stagnant national anti-corruption effort; corruption eradication is by no means a new concept in Indonesia, as anti-corruption activities have actually existed since the 1950s. One of the main reasons why these previous efforts have not been successful is that they only focused on repressive actions: pre-investigating, investigating, and prosecuting corrupt acts. Although repressive operations are vital for the success of corruption eradication, these past efforts failed in the medium to long term due to the lack of significant preventive actions.

The KPK is therefore a fresh start, a new way of looking at the corruption epidemic: the agency shall not monopolize the anti-corruption effort, but merely act as a trigger mechanism to empower authorized institutions to become more effective. Selected cases are handled by the KPK, in order to show the public that it is serious; prevention activities such as socialization, education, research into the potentials for corruption of each government institution, and so on, provide the basis for a long-term anti-corruption strategy. Of course, prevention activities will likewise fail if the KPK is unable to show corruptors and the public that it means business by actively bringing down corruptors.

Duties and Authority of the KPK: 1) Coordination with and supervision of other institutions authorized to eradicate corruption; 2) Conduct pre-investiga- 
tions, investigations, and prosecutions against corrupt acts; 3) Conduct preventive actions against corruption; and 4) Monitor state governance.

The KPK coordinates its activities through the Prosecutor's Office, the Police, and various financial supervisory and regulatory bodies and also: 1) Provides a reporting system to aid corruption eradication; 2) Requests information on corruption eradicating activities from relevant institutions; 3) Conducts consultation hearings or meetings with authorized institutions; 4) Requests corruption prevention reports from relevant institutions.

The KPK's supervisory role includes surveillance, research, or studies on authorized corruption eradication institutions and those that perform public services. The KPK may also take over the investigations or prosecutions conducted by the Police or the Prosecutor's Office in the following circumstances: 1) A public corruption report is not acted upon; 2) Incompetence or delays in corruption cases without sufficient reason; 3) Suspected bias in favor of perpetrator(s) or indications of corrupt elements in conduct of investigations; 4) Obstructions to the handling of a corruption case due to executive, judicial, or legislative intervention; or 5) Other circumstances which have hindered the capability of the Police or the Prosecutor's Office to conduct a proper investigation

The KPK's purview in corruption investigation includes these circumstances: 1) Involvement of law enforcers, state officials, and other connected individuals; 2) Significant public concern; and/or: 3) At least one billion Rupiah in value (approx US\$100,000).

The KPK's purview in preventive measures includes: 1) Audits on the wealth of state officials; 2) Reviews of graft reports; 3) Anti-corruption education programmes at all levels of education; 4) Design and promotion of corruption eradication social programmes; 5) Anti-corruption campaigns for the public; 6) Studies on management systems of all state and governmental agencies, with a view to making improvements to reduce the potential for corruption.

The principal provisions which relate to corruption offences are contained in Indonesia's Criminal Code. However, Law No. 31 of 1999 on the Eradication of the Criminal Act of Corruption ("Law No. 31/1999") as amended by Law No. 20/2001 on the Amendment to Law No. 31/1999 on the Eradication of the 
Criminal Act of Corruption ("Law No. 20/2001"), expands upon and adds to these criminal offences and, not surprisingly, increases significantly the penalties for breach of the Criminal Code provisions (which, to a large extent are now fully incorporated into Law No. 31/1999).

A few of the provisions of Law No. 31/1999 which have been taken from the Criminal Code and which are relevant for our purposes are as follows (note that in October 2010, Rp.1,000,000.- was approximately equal to US\$90):

Article 5

Sentenced to a minimum of 1 (one) year and maximum of 5 (five) years imprisonment and or fined a minimum Rp. 50,000,000 (fifty million rupiah) and maximum of Rp. 250,000,000 (two hundred and fifty million rupiah) shall be anyone who:

1) gives or promises something to a civil servant or state operator with the intention for such civil servant or state operator to commit or not to commit something in his position, that contradicts with his obligations; or

2) gives something to a civil servant or state operator due to or in relation to something which the official has done or not done in his position and which contradicts with his obligation.

3) A civil servant or state operator receiving gifts or promises as mentioned in paragraph (1) letter a or letter $b$, may be sentenced with the sentences as referred to in paragraph (1).

\section{Article 11}

Sentenced to a minimum of 1 (one) year and maximum of 5 (five) years of imprisonment and fined a minimum of Rp. 50,000,000 (fifty million rupiah) and maximum of Rp. 250,000,000 (two hundred and fifty million rupiah), shall be any civil servant or state operator who receives presents or promises whereby it is known or can be suspected that such presents or promises were given due to the power and authority attaching to his position, or in the opinion of the person providing the presents or promises, such presents/ promises are related to his position.

\section{Article 12}

Sentenced to life or a minimum of 4 (four) years and maximum of 20 (twenty) years of imprisonment and fined a minimum of Rp. 200,000,000 (two hundred million rupiah) and maximum of Rp. 1,000,000,000 (one billion rupiah) shall be any:

1) civil servant or state operator receiving presents or promises, where it is known or can be suspected that such presents or promises were given to influence the civil servant or state operator to commit or not to commit something under his position, which contradicts with his obligations; 
2) civil servant or state operator receiving presents or promises, where it is known or is reasonably suspected that such presents were given due to or caused by something that has or has not been committed with regard to his position that contradicts with his obligations;

3) judge receiving presents or promises, where it is known or is reasonably suspected that such presents or promises were given to influence the decision of a case handed to the judge for trial;

4) person who according to provisions of the law is appointed as an advocate to be present at a court trial, and who receives presents or promises, where it is known or is reasonably suspected that such presents or promises were given to influence the advice and opinion that will be given, in relation to a case handed to the court for trial;

5) civil servant or state operator who with illegal intention to make himself or another person rich, or by way of abusing the authority forces someone to give something, pay, or to accept payment with discount, or to commit something for himself;

6) civil servant or state operator who at the time he undertakes his duties, requests, receives from, or withholds payment to another civil servant or state operator or to general cash, as if the other civil servant or state operator or public account is indebted to him, although it is known that such matter is not a debt;

7) civil servant or state operator who at the time he undertakes his duties, requests or accepts work, or delivers goods, as if such is considered as a debt to him, while it is known that such is not a debt;

8) civil servant or state operator who at the time he undertakes his duties, has used state land with the Right to Use title, as if in accordance with regulations, and has caused loss to the rightful holder, while it is known that such act is not in accordance with laws and regulations; or

9) civil servant or state operator who directly or indirectly participates intentionally in any contracting, procurement or leasing, and who while committing such act, is fully or partially assigned to manage and supervise it.

There are a number of other provisions but these, for the most part, relate to specific ircumstances such as the bribery of judges, corruption in government procurement contracts and extortion by government officials.

Law No. 31/1999, replaces and revokes the previous law on the eradication of the criminal act of corruption, namely Law No. 3/1971. It is important to understand how Law No. 31/1999 (as amended by Law No. 20/2001) improves and expands upon and differs from, Law No. 3/1971.

In brief, Law No. 31/1999 does the following:

1) it expands the definition of "government official 
2) it adds new, and increases the minimum and maximum fines and custodial sentences for old, offences;

3) it expands the definition of the criminal act of corruption and introduces a cross-border or transnational element;

4) it details the concept of the officers of a company being liable for the criminal actions of the company's employees;

5) it attempts to ease the investigation and prosecution of criminal acts;

6) it provides for the establishment of, initially, both a joint team and, ultimately, a commission for eradication of the criminal act of corruption.

7) it enables the public to assist and participate in eradicating corruption.

These, together with other important provisions of Law No. 31/1999 and Law No. 20/2001 will now be looked at in further detail.

\section{Expanded Definition of Government Employee}

One of the major concepts introduced by Law No. 31/1999 and Law No. 20/2001 is the broader definition of a "government employee". The definition in full is as follows:

"In this Law:

[2] Government Employees shall cover:

a. Government Employees as referred to in the Employment Law

b. Government Employees as referred to in the Criminal Code

c. People receiving salaries or wages from state finance or regional finance.

d. People receiving salaries or wages from a corporation which receives assistance from state finance or regional finance, or

e. People receiving salaries or wages from other corporations which use capital or facilities from the state or from the public.

As can be noted, c., d, and e. above will include a large number of enterprises. These might conceivably even include all foreign investment companies which enjoy master list facilities, as well as banks which have received liquidity loans.

\section{New Criminal Offences and Increased Penalties}

Law No. 31/1999 increased the penalties for many of the Criminal Code offences referred to in point " $b$ " above. Another interesting concept introduced by Law No. 31/1999 and which relates to penalties is the ability of the court to order the confiscation of assets and even the revocation of business licences and permits. 
So far as "new" offences are concerned, the provisions of Articles 2, 3, and 13 should be noted, as follows:

Article 2

1) Anybody who illegally commits an act to enrich himself or another person or a corporation which may cause loss to the state finance or state economy, shall be sentenced to life imprisonment or minimum imprisonment of 4 (four) years and a maximum of 20 (twenty) years, and a minimum fine of Rp. 200,000,000 (two hundred million rupiah) and a maximum fine of Rp. 1,000,000,000 (one billion rupiah).

2) In the event that the criminal act of corruption as referred to in paragraph (1) is committed under certain circumstances, the person concerned may be sentenced to life imprisonment."

\section{Article 3}

"Anybody who with the intention to earn profit for himself or another person or a corporation, abuses the authority, opportunity or facilities given to him on account of his post or position which may cause loss to the state finance or state economy, shall be sentenced to life imprisonment or a minimum sentence of 1 (one) year and a maximum of 20 (twenty years) or a minimum fine of Rp.50,000,000 (fifty million rupiah) and a maximum fine of Rp.1,000,000,000 (one billion rupiah)."

\section{Article 13}

"Anybody giving presents or promises to a Government Employee in relation to the power or authority vested in the post or position, or by giving gifts or promises considered as vested in the post or position, shall be sentenced to a maximum of 3 (three years) imprisonment and or a maximum fine of Rp.150,000,000 (one hundred and fifty million rupiah)."

\section{Equitable Sentences and Gratifications}

Following on from the above, Law No. 20/2001 introduced two new and interesting additions to the sentencing/punishment provisions of Law No. 31/1999. First, the increased imprisonment and fines imposed for breach of Articles 5 to 12 of Law No. 31/1999 are not applicable for corrupt acts involving amounts of less than Rp. 5,000,000. In such circumstances, the maximum term of imprisonment is 3 years and the maximum fine is Rp. 50,000,000.

Secondly, Law No. 20/2001 introduced the concept of "gratifications" given to public officials and determines when and how these may be considered as bribery. If the gratification (which can be a gift in basically any form, including free 
travel tickets, accommodation, discounts, commissions or medical treatment among others) has a value of Rp.10,000,000 or more then the recipient is obliged to prove that the gratification is not bribery. If the value is less than Rp. $10,000,000$ then proof of bribery remains with the public prosecutor.

In the case of gratifications two further points are of interest. First, the penalty for breach of the relevant article is only imposed on the recipient. Secondly, the receipt of a gratification is not a crime if the recipient reports the gift to the Commission for the Eradication of the Criminal Act of Corruption. The Commission will then decide whether the gratification can be kept by the reporting recipient or should become State property.

\section{Expansion of Definition and Cross-Border Element}

The criminal act of corruption now covers those who attempt or assist or consult in such acts. In addition, anybody (this can be an individual or a corporation) outside the territory of Indonesia "who provides assistance, opportunity, facilities or information to create a criminal act of corruption" shall also be guilty of the relevant offence. Accordingly, if a foreign investment company's regional or head office provides funds which are used to bribe government officials then the regional or head office will also be subject to punishment.

On the other hand, corruption is derived from the Latin verb rumpere, to break. According to this approach, corruption is where the law is clearly broken. This requires that all laws must be precisely stated, leaving no doubts about their meaning and no discretion to the public officials. A legal interpretation of corruption provides a clearly demarcated boundary between what is a corrupt activity and what is not. 'If an official's act is prohibited by laws established by the government, it is corrupt; if it is not prohibited, it is not corrupt even if it is abusive or unethical. ${ }^{9}$

In the light of the points raised in the introduction, it becomes pertinent to clearly define this concept and its various branches so as to get to understand what it actually means. Corruption has received considerable attention in the developed societies, and perhaps, due to the fact that it has been over-flogged in the academic circles, corruption has received varied definitions. Corruption has

9John A. Gardiner. “Defining Corruption,” in: Corruption and Reform 7,1993. 
broadly been defined as pervasion or change from good to bad. Specifically, corruption or corrupt behaviour involves violation of established rules for personal gain and profit. ${ }^{10}$

In common usage, the word corruption is associated with a range of acts such as bribery, extortion, buying influence, nepotism, favoritism, fraud and embezzlement. Nevertheless, it is at root evidence of a moral failure. The word corruption comes from the Latin verb rumpere, to break. ${ }^{11}$

By implication, then, something is broken - presumably a prevailing ethical, moral, social, or administrative code of conduct. In this respect, corruption can be thought of as the betrayal and abuse of trust for private benefit.12

A number of corollaries follow. First, there can be no clear distinction between perpetrator and victim. If ethics are good for you, then corruption must be corrosive to the perpetrator, along with society as a whole. Second, there is necessarily a cultural dimension. Such actions as officials demanding bribes are considered corrupt in virtually all societies, whereas attitudes to giftgiving and cronyism, for example, vary from country to country. ${ }^{13}$

Gould have argued that there is no single definition of corruption which can be accepted by all peoples of different places and times. ${ }^{14}$ Corruption may be different from region to region, and from time to time. Some authors have defined corruption simply as power or public role abuse for private gain, ${ }^{15}$ but Nye ${ }^{16}$ proposed a more complex and longer definition of corruption, as: behaviour which deviates from the normal duties of a public role because of private-regarding (family, close private clique) pecuniary or status gain; or violate rules against the exercise of certain types of private-regarding influence. This includes such behaviour as bribery (use of reward to pervert the judgement of a person in a position of trust); nepotism (bestowal of patronage by

\footnotetext{
${ }^{10}$ Shah, "Corruption: Global issues; Social, Political, Economic and Environmentalissues that affects us all". http://www.globalissues.org/article/590/corruption, 2011, retrieved: 05/10/2016.

${ }^{11}$ C. Camerer, "Gifts as Economic Signals and Social Symbols."

${ }^{12}$ Arnold J. Heidenheimer, (ed.), Political Corruption: Readings in Comparative Analysis, p. 4.

${ }^{13}$ Samuel P. Huntington, Political Order in Changing Societies, p. 59.

${ }^{14}$ Gould, D.J... "Administrative corruption: incidence, causes, and remedies”.

15Johnston, M., Political Corruption and Public Policy in America.

${ }^{16}$ Nye, J.S., 'Corruption and Political Development: a Cost-benefit Analysis', p. 417.
} 
reason of ascriptive relationship rather than merit); and misappropriation (illegal appropriation of public resources for private-regarding uses.

One of the main challenges for the eradication of corruption in Indonesia is the establishment of an effective and efficient anti-corruption program which involves public participation. One problem is that the corruptor fights back with harassment, intimidation and criminalization. For example 'revisions' of law by parliament are used to weaken the KPK laws. Other issues are the limited infrastructure of the KPK, managing the expectations of the public and budget constraints. In the last three years it was tried to review the Criminal Code and Procedure to make corruption an ordinary crime. It is the task of the people to prevent this. Strengthening institutions and legal cooperation from the perspective of institutional capacity development, also taking into account the donors' view on capacity development. Capacity development is an endogenous process. Organizations are open systems, they are in constant interaction with the outside world. External action plays a very modest role. There is a general acknowledgment that corruption permeates both public and private spheres. To get bureaucratic tasks done promptly has long required an informal payment of some sort. To get anything done in the parliament appears to be no different, with 'envelope' politics a common phenomenon. While anti-corruption initiatives such as the establishment of the Corruption Eradication Commission (KPK) and various projects by civil society groups attempt to change the status quo, the reach of corruption seems undeniable, even if it has now taken on new forms. And the 'ruleof law' - meaning, at a minimum, a political system in which the government obeys its own laws and applies them consistently, without regard to the identity or power of particular individuals - is a complex institution: 'the exceptional, not the usual, method of social ordering. ${ }^{17}$

Nevertheless, a number of cutting-edge facts show the opposite tendency, widespread corruption, and rampant vulgarity. The development of corrupt practices is increasing, from year to year both in terms of quantity or amount of losses to the state and in terms of the quality of the increasingly systematic, sophisticated and scope after expanding in all aspects of society. Overview the

\footnotetext{
${ }^{17}$ Goodpaster, Gary, 'The Rule of Law,Economic Development and Indonesia', in Timothy Lindsey (ed.), Indonesia: Law and Societ (Sydney: The Federation Press, 1999), pp. 21-32.
} 
treatment of combating corruption very weakness, is also shown by the perpetrators of the corruption that has adequate indicted were acquitted or escape from the law. Even if some of them convicted, but the number is relatively small and the sanctions imposed against the perpetrators of corruption are relatively very light, does not correspond with the actions undertaken. William J.Chambliss in Syamsudin argued that the corruption involved many parties called network of corruption. He saw that corruption is an integral part of any bureaucracy that meet the interests of a handful of entrepreneurs, law enforcement, and politicians are difficult to break. Network corruption involving elites in power: the helm of the executive, the elite political parties, judiciary officials and business circles. ${ }^{18}$

In Indonesia, public sector products, including, for instance decisions and licences, are valuable because demand for them usually exceeds supply. This is worsened by expanding role of the state and the fact that official procedures are usually time-consuming, uncertain, impersonal and expensive. ${ }^{19}$

Bribery a very popular term in Indonesia, but in fact not new in Indonesia. Connotations primary form of the term is a promise, lure or granting benefits inappropriate by someone to officials or civil servants, directly or indirectly, with the intention that the civil servant or the official acts or omissions in accordance with his duties legitimate. Bribes are no longer seen as a conventional crime, but rather as an extraordinary crime.

Nowadays, bribery prevails in many sectors of numerous societies, to the extent that there is almost no area of life that is free from bribery, especially in third world countries. There is bribery in judgment such that the judge takes the side of the undeserving or prevents someone from having his right, gives precedence to the one who does not deserve to be preferred and vice versa, or is partial in his judgment to a relative or someone of high status -due to an unlawful bribe that he received. There is also bribery in implementing judgment. There is bribery in appointing people when someone pays a bribe to those who are in authority to appoint someone while there are others who are more

\footnotetext{
18M. Syamsudin, “Korupsi dalam Perspektif Budaya Hukum”, UNISIA, Vol. XXX No. 64 June 2007,p.1.

19 Johnston, M. "Micro and Macro Possibilities for Reform", Corruption and Reform, Vol. 7, No. 3, 1993, pp. 189-204.
} 
deserving of the job than him. As with definitions of corruption, theorists disagree as to why public servants behave corruptly. Which forms of corruption are manifest in Indonesia. In Indonesia, bribes are the most common form of corruption in relation to the abuse of the monopoly function of public sector.

Characters bribery and corruption is very criminogen because it can be a source of another crime, and victimogen because it can potentially harm the interests of the various dimensions from small to large. In general, the bribery is a prerequisite to the other corruption offenses. Corruption in a significant amount could pose a threat to the stability and security of societies, undermining the institutions and values of democracy, ethical values and justice, are discriminatory and undermines the ethics and competition honest business, wounding sustainable development and the rule of law as one of the core values of democracy, among others, should be accompanied by enforcement of the principle of equality before the law.

In economic jargon, Gray ${ }^{20}$ describes bribes as the market price which should be paid by consumers to buy certain goods in the form of licences or permits. However, it may be argued that low income as a justification for corruption may only hold true for the 'street-level bureaucrats although there are many Indonesian public servants at this level who perform their duties honestly. The need to supplement a low income can not remain a justifiable excuse for the senior official in the Department of Information, for example, whose salary, together with other incentives and privileges, must be more than adequate.

Gifts are inherent to human relations and therefore present in all cultures. You give and receive gifts on the occasion of birthdays, Santa Claus or Christmas; on the occasion of memorable events; an appointment or a departure; marriage or a retirement. Everybody sees what you give or receive. Such openness is of great importance. In many cultures presenting of gifts is part of the payment traffic. If you make a gift to a village chief in Africa, make it visible to all the villagers who will all benefit from such a gift. When you receive a gift from them, it will also be open and visible to everyone. Corrupt payments

${ }^{20}$ Gray, C., "Civil Service Compensation in Indonesia”, Bulletin of Indonesian Economic Studies, Vol. 15, No. 1, 1979, pp. 65-70. 
are made in hiding, are not made known. A gift made in public will also impose a certain obligation upon the recipient. On a next occasion you will show your gratitude by reciprocating the gift and you share the gift received with your family and friends. In fact, in our everyday life it is not much different. You give and receive on birthdays, on the occasion of marriages and births, and on other festive occasions. Look at the reciprocal state visits of Heads of government and Heads of state, exchanging gifts. Still there is also an ethical problem. Corruption is not only an economical phenomenon in any society or economy. It is not sufficient to call it an economical phenomenon; this ignores the more general importance of a corruption-free society for all aspects of life and for all population groups, poor and rich alike. It also ignores that bribery takes always place within a certain social context. It is a structural problem in companies where the course of actions is not transparent, where the law is not observed, and observance is not monitored.

A striking aspect in recent developments in trade and industry (and in society at large) is the fact that ethics has become important to corporate behaviour again. Standards and values are seen as essential conditions and characteristics for the good quality of citizenship, entrepreneurship and governance. The concepts 'people, planet and profit' are now cherished all over the world in enterprises and often referred to in their annual reports. They emphasize the fact that in a business-enterprise it is not only pursuit of 'profit' that counts, but that businesses should also take into account the interests of 'people' in our society (people, their personnel, executive staff, shareholders, clients, neighbours, etc.) and also the physical world surrounding us, our 'planet', introducing economical management of raw materials and energy, concern about possible climate, prevention of waste, processing of waste. Apart from the economics and the financial outcomes of entrepreneurial decisions, socially and ecologically justifiable behavior is now also identified as being important.

The Indonesian public seems to tolerate corruption. Two factors may explain this phenomenon. Firstly, the people are apathetic because they have lived with corruption for such a long time that it has become a habit. The history of corruption in Indonesia, according to Anderson, began in the time of World War II, when the arbitrary reduction of salaries through inflation meant that in 
less than four years the Indonesian rupiah sank to one sixtieth of its previous value. Since then, corruption has remain a stubborn feature of the republic. began in the time of World War II, when the arbitrary reduction of salaries through inflation meant that in less than four years the Indonesian rupiah sank to one sixtieth of its previous value. Since then, corruption has remain a stubborn feature of the republic. Secondly, public ignorance toward corruption may sometimes be related to cultural practices or traditions. Since forty percent of the Indonesian population is Javanese, and in many cases dominate the key positions in public sector, Javanese culture is often blamed for the practices of corruption, collusion, and nepotism in the public service. ${ }^{21}$

Briefly, the anti-corruption movement includes two-stage processes: first, the stage of policy formulation to address the main root-causes of corruption; and, second, the stage of creating and enhancing political will which is crucial for the implementation of anti-corruption programmes.The two-stage processes reflect the crucial role of government and bureaucracy in the war against corruption. This is, of course, only one of the first steps towards the creation of a democratic, credible, accountable government in the management of the public sector. Therefore, the first crucial step in the eradication of corruption is to accelerate the demands and pressures for reforms at the level of government, then at the level of business sector, and finally at the level of the public in general. One of the most important determining factors in the success of anticorruption efforts is the political will at the highest level of government. Having conducted a number of studies on corruption, Morgan points out that one conclusion which often emerges is that a sincere commitment by high level leadership to counter-corruption efforts is a crucial component of successful campaigns. $^{22}$

In Indonesia, a majority Muslim country -in fact the largest Muslim country in the world- a large number of Islam-based civil societies exist. So, the question can Islam society in Indonesia teachings against corruption, and the recent experiences of Indonesia in combating this vice, particularly the role of

\footnotetext{
${ }^{21}$ Anderson, R.O.G. Java in a Time of Revolution, Ithaca, New York, 1972.

${ }^{22}$ Amanda L. Morgan, Corruption: Causes, Consequences, and Policy Implications: A Literature Review (San Francisco: The Asia Foundation, 1998), p. 6.
} 
an Islamic civil society sphere. The sorry lack of political will shown in the KPKPolice represents how reform of the police sector may also be problematic. There is increasing concern that any significant anti-corruption efforts will stunt economic growth, as increased caution delays investment and development. Corruption has been largely overlooked within the Muslim communities, this paper primarily objectives of elucidating the Islamic practices position and to examine if Muslim majority countries and communities are actually implementing Islamic practices towards abolition and eradication of corruption in their own States and societies. Corruption as a severe threat to the social, economic, and ecological balance and reveals in details the various Islamic dispositions and punishment which are meant to curb the endemic practices of corruption across States and boarders.

By contrast, in Islam corruption is seen in its core as a moral problem, and as such one which involves second-order preferences that are at risk of being modified over time.

As Nerlich argues It is a necessary, though not a sufficient condition of any moral self-appraisal that one have second-order desires, and of one's moral effectiveness that one can carry through some course of second-order action." Translated into the Islamic agenda, if there can be a moral regeneration and a commitment to social justice and the public interest, all else should follow. If it does not, the outcome may reflect one or more of two things: 1) weakness of internal restraint internalization of Islamic values and cognisance of strict accountability due to a falling apart of traditional education system; 2) weakness of external restraints due to sticking neither with the Sharia nor with developments in secular law and institutions. What is then needed is to rediscover the faith, values, egalitarianism and transparency of the early Islamic state and the early caliphate.

There are numerous definitions among Muslim jurists. Some scholars state that bribery (rashwa) is the principle form of corruption and define it as what is given to invalidate a right (haqq) or to validate a deception or falsehood (bāttil). Others say that bribery is a gift, whether in real or monetary terms, presented to judges and other decision makers to facilitate a favorable ruling or judgment. Other jurists say bribery is an abuse of judicial oradministrative power or of political authority, trust, or financial prowess. 
Illegal earnings -its means prohibited earnings and the maximization of profits in an illegitimate manner- bribery given to the witness to testify, the judge to rule, and the price of power.|l It is the kind of corrupt behavior explained by the following Qur'anic verse: They are fond of listening to falsehood, of devouring anything forbidden. There is general agreement that religion and ethics are closely linked. Religion provides a system of norms and values guiding how individuals should live. Such norms and values are often codified as religious beliefs in the Bible or the Quran.

As has been described above that corruption according Syafi'iyyah categorized to the majority of scholars in al-ghulül (betrayal of the treasures entrusted) and al-ghashsh (fraud) then the substance of corruption returned to the law of al-ghulūl and al-ghashsh itself ,

On the issue of al-ghulūl, Allah says:

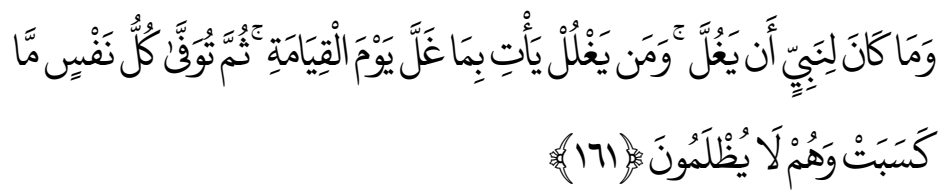

"There may be a prophet of treason in the affairs of the spoils. Anyone who defected in the affairs of spoils it, then on the Day of Resurrection he will come to bring what treasonabled it, then every soul will be recompensed what he was doing with (retaliation) in kind, they will not be wronged." 23

According to this verse mufassirin down at Badr, because there are some companions who defected in matters of war treasure. In a hadith that is authentic Prophet sallallaahu 'alaihi wa sallam said:

"Whoever applicable zalim (treasonous in problem assets) piece of land then later on the Day of Judgment will be suspended seven layers of the earth around its neck."24

And still more to explain about the prohibition ghulul and the most serious threats to the actors on the Day of Judgment. Regarding punishment for the perpetrators of al-ghulūl (betrayed by taking possessions ghanimah before distribution), Imam Shafi'i been asked, whether he was told to get down from

${ }^{23}$ QS. Āli Imrān [3]: 161.

${ }^{24}$ Hadith narrated by al-Bukhārīand Muslim. 
the horse and foot, saddle burned or burned property. Shafi'i said: "Not at law (iqāb) a person on his property, but on the body. Verily Allah made al-hudūd on the body, as well as al-'uqūbāt (sanctions), while on the property then there is no 'uqūbāh. In connection with the issue of fraud (al-ghashsh), the Prophet sallallaahu 'alaihi wa sallam said: "Those who cheat then he is not from the class of my people."25 May God save us from the corruption in the world and save us from the torment on the Day of Judgment.

Corruption is one of the evil acts practised by human beings out of selfish motives. It not only creates negative impact on economy of the country but, indirectly, destroys the balance of the social order also. It involves injustice as well as display of might or administrative connections. The Holy Quran warns mankind of the consequence of injustice and violence, and states: "Do not do mischief on the land." Allah asks mankind: "Who is more criminal than those who do injustice? In Islam, actions and deeds are controlled by intention or Niyath. The Holy Prophet (peace and blessings of Allah be to him) said: "Actions are judged by motives, and a man shall have what he intends." The Holy Quran warns mankind in these words: "Do not speak which you do not do." The Blessed Prophet was the living example of this statement, and this is the reason why Thomas Carlyle wrote: "A man of truth and fidelity, true in what he did, in what he spoke and thought. The word of such a man is a voice direct from Nature's own heart."

The lacking of faiths based doctrines on corruption has impacted the study of corruption as a whole in a narrow minded syndrome. As Bukovansky points out, Despite its moral overtones, the bulk of contemporary anti-corruption discourse deploys the language and methodologies ofeconomics and rational choice to render diagnostic assessments of the plight of the corrupt and less developed. 26

In the early Islamic community, equality, accountability, anda high degree of transparency in the early Caliphate sawpublic funds handled with great caution and care, withmilitary expeditions to prevent corruption.Acceptance of

\footnotetext{
${ }^{25}$ Hadith narrated by Muslim and others.

${ }^{26}$ Bukovansky, M., "The hollowness of the Anti-corruption Discourse," Review of International Political Economy, Vol. 13, No. 2, 2006, p 181-209.
} 
what constitutes corrupt behavior is culture specific andvarious from country to country. Did pre-Islamic Arab cultural values overtake Islam's universal values? Or did the failure result from the Muslims' inability to actualize their preferred set of norms via rationally designed institutions,lately even for such simple tasks as education in Islamicethics?

The suggestion now is that ethics can empower aswell as constrain. ${ }^{27}$ Religious and moral educations of all spheres of ourtransactions if guided by proper application of religiousvalues, social justice, and linking them with a broader worldview will help crime prevention and serve as both deterrence and rehabilitation by the application of Islamic principles for punishment. Equally important are the significant ethical and moral dimensions to reducing corruption, if only because there are situations where the external constraints confronting officials are weak and self-restraint is needed. Ethics can be empowering, as well as making good practical sense, since ultimately everyone benefits from the behavioral boundaries that ethics dictate. There is room for isolation of Islamic for combating corruption. This is how Islam molded the Muslim community. Indonesian has a majority muslim muslim country have potential as a leader in the fight against corruption.

\section{Conclusion}

Corruption is a problem for both developed and developing countries. In Indonesia, corrupt practices are triggered by; the monopoly functions of the public sector in delivering certain services; poverty and low public sector incomes; traditional values; ignorance; and the form of government. Although some strategies to combat corruption have been identified, these are unlikely to succeed in Indonesia so long as the government remains undemocratic. Corruption has been largely over looked within the Muslim communities if Muslim majority countries and communities are actually implementing Islamic practices towards abolition and eradication of corruption in their own States and societies. However, it is within this framework of divine mercy and justice

\footnotetext{
${ }^{27}$ Adam Smith, "The Theory of Moral Sentiments", in D. D. Raphael \& Benjamin C.D. Diara, and Nkechinyere G. Onah, (eds.) "Corruption and Nigeria's Underdevelopment: a Religious Approach," Research on Humanities and Social Sciences,, Vol.4, No. 4, 2014.
} 
that a Muslim should belief that God is fully aware of his abilities and limitations, and will not overburden him or subject him to any duress or coercion. There are several factors that affect law enforcement, the law that is already listed in the legislation, the parties to uphold the law itself, means or facilities in law enforcement, the law contained in the environmental community, and its own culture (values are listed). Ineffective of law in Indonesia is also dependent on these factors.[w] 


\section{BIBILIOGRAPHY}

Adam Smith, "The Theory of Moral Sentiments", in D. D. Raphael \& Benjamin C.D. Diara, and Nkechinyere G. Onah, (eds.) "Corruption and Nigeria's Underdevelopment: a Religious Approach," Research on Humanities and Social Sciences, Vol.4, No. 4, 2014.

Aji, B., 'Menekan ICOR dengan Antibocor', Forum Keadilan, 1995.

Amanda L. Morgan, Corruption: Causes, Consequences, and Policy Implications: A Literature Review, San Francisco: The Asia Foundation, 1998.

Anderson, R.O.G.Java in a Time of Revolution, Ithaca, New York, 1972.

Arnold J. Heidenheimer, ed., Political Corruption: Readings in Comparative Analysis, New York: Holt, Rinehart and Winston, Inc., 1970.

Bukovansky, M. (ed.), “The Hollowness of the Anticorruption Discourse”, Review of International Political Economy, Vol. 13, No. 2, 2006.

Camerer, C., "Gifts as Economic Signals and Social Symbols," American Journal of Sociology, Vol. 94 (supplement), 1988.

Goodpaster, Gary, "'The Rule of Law, Economic Development and Indonesia", in Timothy Lindsey (ed.), Indonesia: Law and Society, Sydney: The Federation Press, 1999.

Gould, D.J.,. 'Administrative Corruption: Incidence, Causes, and Remedies' in A. Farazmand. (ed.), Handbook of Comparative Development and Public Administration, New York: Marcel Dekker, 1991.

Gray, C., "Civil Service Compensation in Indonesia", Bulletin of Indonesian Economic Studies, 1979.

Huntington, Samuel P., Political Order in Changing Societies, New Haven and London: Yale University Press, 1968.

John A. Gardiner. "Defining Corruption," in: Corruption and Reform 7, 1993.

Johnston, M., Political Corruption and Public Policy in America, California: Brooks/Cole Publishing: 1982.

"Micro and Macro Possibilities for Reform", Corruption and Reform Vol. 7, 1993. 
Nye, J.S.,. "Corruption and Political Development: a Cost-benefit Analysis", in M.U. Ekpo (ed.), Bureaucratic Corruption in Sub-Saharan Africa: toward a Search for Causes and Cosequences, Washington D.C: University Press of America, 1979.

Shah, "Corruption: Global Issues; Social, Political, Economic and Environmental Issues that affects us all". http://www.globalissues.org/article/590/ corruption, 2011, retrieved: 05/10/2016.

Syed Hussein Alatas, Corruption: Its Nature, Causes and Consequences, Aldershot [UK] and Brookfield VT: Avebury, 1990. 